\title{
The Debate on the Concept of Flexicurity at the European Union Level
}

Hasan Faruk USLU*

\begin{abstract}
The aim of this article is to focus on the concept of flexicurity, accepted as the new labour market model balancing the needs of employers for greater flexibility in order to adapt to market forces, and the need of employees for security, which has recently been one of the most popular concepts of the debate on labour market reforms in the European Union (EU). While doing so, this article discusses the position of key European institutions, especially of the Commission of the European Communities (CEC). The main argument is that the concept is still very open to alternative interpretations at the EU level. Related to this openness is the fact that the Commission has deliberately instrumentalized the concept's ambiguity in order to absorb all the main actors into the debate in line with its own policy preferences.
\end{abstract}

Keywords: Flexicurity, Deliberate ambiguity, EU, Commission

\section{Avrupa Birliği Düzeyinde Güvenceli Esneklik Kavramı Üzerindeki Tartışmalar}

Öz

$\mathrm{Bu}$ çalışmanın amacı, son zamanlarda Avrupa Birliğìndeki işgücü piyasası reformları üzerindeki tartışmalarda en gözde kavramlardan biri haline gelen; işverenlerin piyasa koşullarına uyum sağlamak için daha çok esneklik ihtiyaçları ile, işçilerin güvenlik ihtiyaçlarını dengelediği kabul edilen, güvenceli esneklik kavramına yoğunlaşmaktır. Bu yapılırken, kilit Avrupa Birliği kurumlarının, özellikle Avrupa Toplulukları Komisyonu'nun, kavram üzerinde benimsedikleri tutumlar tartışılmaktadır. Kavramın Avrupa Birliği düzeyinde halen alternatif yorumlamalara açık olduğu ve bununla alakalı olarak, Avrupa Toplulukları Komisyonu’nun diğer tüm ana aktörleri tartışmaya çekebilmek için kavramı kasıtlı olarak muğlak araçsallaştırmış olduğu, bu çalışmanın başlıca argümanı olacaktır.

Anahtar kelimeler: Güvenceli esneklik, Kasıtlı muğlaklık, AB, Komisyon

\footnotetext{
* Dr., Department of Public Administration, Atatürk University. E-mail: hasfarus@yahoo.com.
} 


\section{Introduction}

There is no doubt that the term "flexicurity" has been a buzzword since the mid-1990s. This should be primarily attributed to the Dutch and Danish successes ${ }^{1}$ in managing to substantially reduce unemployment rates over the course of the 1990s. Moreover, "flexicurity" has been at the top of the agenda of the European Union with regard to labour market reforms since 2006. The basic assumption of the term is that flexibility of labour markets and security of employees are not mutually exclusive (Frederiksen, 2007). On the other hand, the notion of flexicurity which suggests a reconciliation between flexibility and security may well be considered as a "genuine paradox". In traditional understanding, the flexibility needs of employers and security needs of employees are "irreconcilable opposites" or even "mutually exclusive". Thus the concept is inherently contradictory and conceptually ambiguous (Serrano Pascual, 2009). The flexicurity is put forward to overcome this traditional contraposition (Keune and Serrano Pascual, 2014)

Regarding the literature on flexicurity, it is fair to argue that many people agree on the "ambiguous" character of the concept and the "attractiveness" in this ambiguity (Jørgensen and Madsen, 2007; Keune, 2008; Seifert, 2008; Bredgaard and Larsen, 2007). Due to a lack of "the theory of flexicurity", everyone is happy with the term (Seifert, 2008). The concept is used in many different contexts and many different definitions can be noted. Some people consider it within the framework of "Third Way" thinking (Ashiaghbor, 2005:281-285) or "the middle ground between Eurostagnation and cruel capitalism" (Fitch, 2007). This is because while it is a critique both to neoliberalism interested in labour market flexibility, and to traditional social democracy, interested in job security. It is argued that the wisdom behind the flexicurity combines some aspects of both. Others view it, especially with particular reference to the Danish system, as a " $a$ hybrid of free labour markets, unfettered business and adjusting welfare to give incentives for people to work so they can pay taxes to finance the benefits they get" (USA Today, March 07, 2007) or "dynamic labour markets and low unemployment coupled with generous support for those who lose their jobs" (Economist, January 20, 2007)2.

The definitions put forward in the academic literature, in particular, also vary. In the first group, flexicurity is considered as a policy strategy:

"A policy strategy that attempts, synchronically and in a deliberate way, to enhance the flexibility of labour markets, work organisation and labour relations on the one hand, and to enhance security - employment security and social security - notably for weaker groups in and outside the labour market, on the other hand" (Wilthagen and Tros, 2004:169).

1 In the flexicurity literature, there are views considering the success of Danish model as "overrated". Keune (2007:2) argues that explaining the Danish success solely by the type of labour market regulations without due attention paid to the elements of macro-economic conditions, wage policies, fiscal policies and industrial relations system is "reductionist". In the Dutch case, the amount of part-time employment was around \%50 in 2007 and when it is adapted to full-time equivalents, it is (officially \% 73.2 in 2005) very close to the German one (\% 65.4 in 2005).

2 It is noteworthy that the main Anglo-Saxon press has developed an interest in the flexicurity debate, albeit focusing solely on the Danish case. Perhaps, the reason should be that the Danish model as having a more "liberal labour market in which it is easy to hire and fire" (Frederiksen, 2007) which seems to be comparable to the Anglo-Saxon countries. 
It is generally accepted that this definition simply comes from the Dutch context. The discovery of the Danish case ${ }^{3}$ which is different from the Dutch one has played an important role in the debate over the definitions of flexicurity. It brought new considerations into the relations between flexibility and security. Labour market researchers started to search for a definition that would be capable of combining the both, which paved the way for the "flexicurity as a certain state of labour market" definition:

"Flexicurity is (1) a degree of job, employment, income and 'combination' security that facilitates the labour market careers and biographies of workers with a relatively weak position and allows for enduring and high quality labour market participation and social inclusion, while at the same time providing (2) a degree of numerical (both external and internal), functional and wage flexibility that allows for labour markets' (and individual companies') timely and adequate adjustment to changing conditions in order to maintain and enhance competitiveness and productivity" (Wilthagen and Tros, 2004:170).

It is fair to argue that at the EU level, the ambiguity on the concept and the attractiveness in this ambiguity is not devoid of political significance in itself. The European Commission has started to popularise the concept since the early 2006. Its flexicurity discourse has been successful in terms of incorporating other key European actors (namely the Council, the Parliament, BusinessEurope and the ETUC) regarding labour markets into the debate. However, the ambiguity applied by the Commission is not an ordinary ambiguity. The failure of the Constitutional project in France and the Netherlands in 2005 in where social considerations of the Europeans played a certain role, the incorporation of the Employment Guidelines into the Broad Economic Policy Guidelines, which could be considered as relegating the social to a secondary position in times of crisis (Jørgensen and Madsen 2007) at the mid-term revision of the Lisbon Strategy in 2005 have led the Commission to "show a social face" to the Europeans in dealing with the legitimacy crisis of the integration process. In this respect, flexicurity was a nice option.

Having provided a brief introduction, this paper will try to shed lights on the ambiguity of concept and the attractiveness in this ambiguity at the EU level. In other words, "what this ambiguity implies, what purposes it serves, whether it is fabricated or not, and what kind of ambiguity this is" are the issues that will be analysed in this paper.

3 This study is too short to be able to provide the details of both models. However, briefly noting the main differences between the models should be functional. Jørgensen and Madsen (2007:11-14) notes the following features of the Dutch flexicurity model in comparison with the Danish system. First of all, the legislation that led to the Dutch flexicurity system should be regarded as a path-dependent element of Dutch corporatist roots, but the legislation was rather a "policy strategy" of the 1990s. Secondly, compared to the Danish system, it is focused on "weaker groups" in the labour market. Thirdly, in sharp contrast to the Danish flexicurity system which builds on "governance without much government as to labour law and regulation", the Dutch system builds on "governmental regulation of employment and security". In the Dutch context, "politicians engaging in elaboration of deliberative flexicurity policies" has been the case. 


\section{The Concept of Flexicurity at the European Union Level}

The European integration process has been driven by two internally contested and overlapping discourses: an economic policy discourse and a social policy discourse. From the interaction between economic and social policy, an employment policy discourse emerged (Ashiaghbor, 2005). Before dealing with the issue at hand, it is important to deal with the causes of the problems that the European integration process has faced regarding social priorities and objectives.

The European integration process has long been generally considered as creating an asymmetry between the economic and the labour market/social field, in the words of Fritz Scharpf, between negative and positive integration 4 . Scharpf argued that this "constitutional asymmetry between policies promoting market efficiencies and policies promoting social protection and equality" constrained the European welfare states through the functioning of economic integration and liberalization (Scharpf, 2002). Thus, negative integration limited the range of policy instruments of member states, paving the way for the important social consequences of negative integration in the member states (Keune, 2007:1).

The treaty of Rome (1957) left social and labour market regulations to the hands of the member states $^{5}$. This led to a fundamental difficulty with which EU social and employment policy, in the following years, has been confronted. On the one hand, "negative integration" (e.g. single market agenda) limits national governments' autonomy in designing their welfare systems. On the other hand, member states strongly oppose shifting further social and employment policy competencies upward to the EU (Büchs, 2007:1-2).

The process of dealing with labour market crisis and aiming to establish a common strategy to that end at the supranational level is also problematic due to a lack of legitimacy of EU institutions in the social realm. Unlike the institutionalisation of national social models, the EU lacks a political identity in the social policy field. It is hard to speak about common social identity features as opposed to the European Union's economic identities (for example the Euro and European Central Bank) (Serrano Pascual and Crespo Suárez, 2007:376). Within this perspective, the stronger EU role in social policy would also increase the legitimacy of EU integration which is generally perceived as detrimental to national welfare systems by Europeans (Büchs, 2007).

Despite the fact that we have been witnessing the aims of increasing competencies of Community in the social and labour market areas, the reluctance of member states to give up their competencies

4 "Negative integration" is considered as the "measures that serve to increase market integration by eliminating national restraints on trade and distortions of competition" where as positive integration is about "the development of common European policies to shape the conditions under which markets operate" (quoted in Keune, 2008:92).

5 Scharpf (2002) notes that, in the negotiations leading to Rome, the French Socialist Prime Minister Guy Mollet had tried to make "the harmonization of social regulations and fiscal burdens as a precondition for the integration of the industrial markets" but, in the final package he only got a "commitment from other governments to increase social protection nationally". The author concludes that "the failure of Mollet" paved the way for economic policy discourse to frame the European agenda which resulted in the "constitutional asymmetry between the economic and social policies". 
to supranational authorities has not gone away. This is the central reason for the so-called "soft" character of the Employment Strategy (Ashiaghbor, 2005:72), the open method of coordination and policy concepts such as flexicurity.

The aim of this part is to focus on the analysis dealing with the contribution the European Union makes to flexicurity policies and politics. Taking into consideration the fact that the quest for a flexicurity type win-win strategy has been a major task since the mid-1990s, "the new interest for this balance (the balance between the flexibility and security) in the last years remains to be told" (Barbier, 2007:179). Related to this observation, an effort will be made to comprehend the reasons for the explicit use of the term flexicurity since 2006. While doing so, noting briefly the positions of the main European actors and the role researchers play as experts is crucial, particularly in terms of launching a new "communication strategy", following the decreasing legitimacy of EU institutions, especially of the Commission after the failure of the Constitutional referenda in France and the Netherlands.

As part of an attempt to grasp the meaning attributed to "flexicurity", this part will discuss the stance adopted by key European actors on this subject, in as comprehensive a manner as possible. These institutions are: a) the Commission, considering its Constitutional role as the main part of the decision-making process and the main driver of the flexicurity debate in Europe, b) the Council, c) the European Parliament (EP), together with the most important social partners, d) the European Trade Union Confederations (ETUC) and e) BusinessEurope. The main aim of presenting briefly the positions of these institutions is to enquire as to whether a European consensus on the concept has been reached (Keune, 2007:7) or whether the debate is still open to alternative interpretations and understandings. Within this framework, this part of the paper will mainly shed light to the EU Commission's efforts.

\section{The Commission of the European Communities (CEC)}

The role the CEC (hereinafter the Commission) has been playing in the debate over the concept of flexicurity is of crucial importance due to the characteristics of the Commission. Its role as a disseminator of knowledge and best practices and as a "broker between divergent interests" (Keune and Jepsen, 2007:16) puts the Commission at a pivotal position. Weiss and Wodak, after noting the constitutional preponderance of the Commission and its monopoly in the right of initiative in the legislative procedure of the Community, claim that "the Commission is truly the initiator and driving force of the decision-making process- not only in a formal but also in a material sense of developing political ideas, concepts and strategies" (Weiss and Wodak, 2000:187). Thus, the efforts of the Commission in the debate on the concept of flexicurity deserve special attention.

As Wilthagen and Tros (2004:167) put forward, the flexicurity-type expectations have been present in the EU policy discourse since the 1993 White Paper on Growth, Competitiveness and Employment and formulated explicitly in the 1997 Green Paper called Partnership for a New Organization of Work: “The key issue for employees, management, the social partners and 
policy makers alike is to strike the right balance between flexibility and security". The "flexibilitysecurity nexus", as the authors name it, has become the main target of the European Employment Strategy and a major challenge to the European Social Model (ESM). The authors also cited the formulation of the 2001 European Employment Guideline 13, under the Adaptability pillar. This was an invitation addressed to the social partners, formulated in explicit terms. It asked from them:
"To negotiate and implement at all appropriate levels agreements to modernise the organisation of work, including flexible working arrangements, with the aim of making undertakings productive and competitive, achieving the required balance between flexibility and security, and increasing the quality of jobs" (quoted in Wilthagen and Tros, 2004:168).

Bekker $^{6}$ (2007) in her study analysing the guidelines and proposed measures regarding the adaptability pillar between 1998 and 2006 concluded that at first, the tone of the Commission's guidelines and recommendations were "balanced" between flexibility and security; but especially after 2005, the discourse shifted towards "dealing with flexibility and security as two separate issues". Bekker (2007:11) states that:

"At first the strive was balance between the two, later on the EES speaks of a need for both, which makes flexibility and security two issues that are to be addressed separately... The last formulation of promoting flexibility combined with employment security reconnects the two items, however, narrows the term security down to employment security. Simultaneously the European debate has shifted to flexicurity, a term in which flexibility and security are interwoven."

This observation is of paramount importance regarding the discursive change in that period. It seems in line with the observations regarding the mid-term revision of the Lisbon Strategy in 2005 as evidence of increasing emphasis on flexibility and relegating social to economic policy.

It seems that the quest for striking a right balance between flexibility and security, until 2006, has been considered explicitly within the framework of the EES, and of the adaptability pillar in particular. It led some authors to argue that preferring a new concept - flexicurity- as a discursive tool in order to express this aim has narrowing down the EES as a whole into a discussion of balancing flexibility and security (Keune and Jepsen 2007). However, the EES had three other pillars besides the adaptability pillar and these pillars seem to be devalued. It can be argued that the EES and the Open Method of Coordination (OMC) have promoted a "participatory policymaking" process "empowering actors in ways parallel to the flexicurity basis of the Danish and Dutch systems" (Jørgensen and Madsen, 2007:24). Policy actors adopt similar concepts through participation in European policy networks in dealing with social and employment policies (Büchs, 2007:1-2).

6 Bekker also argues that "the flexibility and security in the EES are mainly approached as flexicurity a state of affairs rather than as a deliberate policy strategy aiming at striking a balance between flexibility and security" (Bekker, 2007) 
The Commission in the 2006 Employment in Europe Report quoted the definition of "flexicurity as a certain state or condition of the labour market" provided by Wilthagen and Tros (CEC, 2006a:77). It noted in that report that "the main thrust of the EU recommendation on flexicurity is to encourage a shift from job security to employment security" (CEC, 2006a:78). This statement clearly supports the claims that employability is the new security.

The Commission Green Paper Modernising labour law to meet the challenges of $21^{\text {st }}$ century aimed "to launch a public debate in the EU on how labour law can evolve to support the Lisbon Strategy's objective of achieving sustainable growth with more and better jobs" (CEC, 2006b:3). The Green Paper was about assessing how labour law at the EU and national level can help the labour market become more flexible while improving security. In the same paper the accent was on employment security for workers (Rogowski, 2008). According to Rogowski, one of the concerns of the Green Paper was the "clear focus on employment protection matters related to new or atypical forms of employment” (Rogowski, 2007:10).

The crucial point related to the Green Paper, for the aim of this paper, is about the changing title and content ${ }^{7}$ of it. By some researchers (Bercusson, 2007:25 and Bekker, 2007), it is argued that the draft version of this paper (September 2006 Draft version) was entitled "Adapting labour law to ensure flexibility and security for all" - which seems to be discursively compatible with flexicurity. After UNICE (now BusinessEurope) had launched a ferocious attack on the draft which led the Secretary General of the ETUC, John Monks, to write to Barroso on October 12 2006 urging him not to draw back from the modest ambition of the Green Paper; the title got its final version as "modernising labour law to meet the challenges of the $21^{\text {st }}$ century". This note seems very important considering the Commission's role as a broker of interests and it should be inferred that, as Weiss and Wodak cited, "It is high time to correct the widely accepted image of the Commission as an institution serving no interests other than the purely European and, therefore, embodying the 'European idea' per se..." (Weiss and Wodak, 2000:192).

The Commission's 2007 Communication "Towards Common Principles of Flexicurity: More and better jobs through flexibility and security" is the most important document in which its main arguments on the concept of flexicurity are outlined. In order to understand its position, some very important points should be noted.

Flexicurity is defined as "an integrated strategy to enhance, at the same time, flexibility and security in the labour market" (CEC, 2007:4). The Commission presents what it understands from security as "employment security rather than job security" and by relying on a report of

7 Ronald Jannsen - the advisor of flexicurity department of the ETUC - states that "the intention was to prevent False Independence. This should be tackled by modern labour law. Initially, it was an agenda of strengthening labour law to tackle the problem of false independence, and then it was turned around into a green paper on labour law and competitiveness to see how labour law could be used to increase competitiveness which is not the idea of labour law. That's not the function of labour law. The function of labour law is to balance the relationships between the employers and employees. But, now suddenly, with the changing title and changing contents, the labour law became an instrument of competitiveness" - emphasises added. Interview with Ronald Jannsen, by the author, Brussels, January 22, 2008. 
Eurobarometer, it argues that Europeans also consider the job security "as a thing of the past" (Ibid:3). In this special Eurobarometer report (October 2006), it was cited that 76\% of Europeans agree with the following statement - "Life-time jobs with the same employer are a thing of the past". The report interpreted it as an indirect support to flexicurity (Special Eurobarometer 261, 2006:14).

The document outlines four components of flexicurity as "flexible and reliable contractual arrangements", "comprehensive lifelong learning strategies", "effective active labour market policies" and "modern social security systems". Not as a component of flexicurity but under another title, it notes the importance of "social dialogue" arguing that integrated flexicurity policies are often found in those countries where social dialogue has played an important role.

Related to flexible and reliable contractual arrangements, the Commission underlines the negative role of Employment Protection Legislation (EPL). It argues for low levels of EPL to increase adaptability and reduce segmentation (Keune, 2007:5). As can be inferred by looking at its predominant components of flexicurity, the Commission believes in the benefits of lifelong learning and effective active labour market policies in order to provide employment security (Wilthagen, 2008). However, as Keune (2007 and 2008) argues while interpreting the Commission's position, "no mechanisms are provided which should contribute to achieving these goals". It is also noteworthy that the Commission has already been calling for many years for these policies with limited results. Jepsen claims that lifelong learning and active labour market policies have been on the agenda for a decade but it is clear that they are not considered as a type of security.

While presenting its views on the financial dimension of flexicurity, the Commission retains a tone that is "vague and ambiguous", saying "good unemployment benefit systems are necessary to offset negative income consequences during job transfers". At the same time, it argues that "unemployment benefits may have a negative effect on the intensity of job search activities and may reduce financial incentives to accept work" (Keune, 2007:5). The Communication also notes that the budgetary costs related to flexicurity policies should remain compatible with sound and financially sustainable budgetary policies (CEC, 2007:11).

The following observation deserves to be quoted at length in order to critically outline the Commission's view in simple terms:

"Flexibility should be provided by low EPL and easy use of flexible contracts while security should derive from employment security...Its call for modern social security remains vague and underspecified... Hence the emphasis in the Commission's conceptualisation is first of all on increasing flexibility, while security remains much less developed. Also, in spite of the claim that flexicurity is a new approach to labour market reform, all these elements have been part and parcel of the European Employment Strategy since 1998" (Keune, 2007:7).

8 Interview with Maria Jepsen (The head of ETUI-REHS Research department and Associate Professor at Université Libre de Bruxelles), January 22, 2008 at ETUI-REHS/Brussels, Belgium. 
The Commission also presented "Eight Common Principles of Flexicurity" to the Council for adoption. The Council adopted a document with these principles of flexicurity very similar to the Commission's propositions but not identical (see the Council part).

The Commission's Communication articulates "general pathways" for member states- reducing asymmetries between non-standard and standard employment; strengthening transition security; broadening and deepening investments in skills; prevent long-term welfare dependence, regularise informal work and build up more institutional capacity for change (Wilthagen 2008) in order to reach a better combination of flexibility and security, by taking their institutional and historical properties into account, largely developed on the basis of the report of the European Expert Group on flexicurity (European Expert Group on flexicurity 2007) and notes "background indicators relevant for flexicurity". The issue of indicators is also noteworthy due to the fact that the Commission has not attempted to present a "composite indicator" for flexicurity, which would be "disastrous for Europe" considering the possibility of ranking member states ${ }^{9}$. Combining the attempts of common principles together with different pathways means that "there are different ways leading to Rome" (Seifert, 2008) or, in other words, "no one-size-fits-all". As stated in the Common Principle 3 "each member state should develop its own flexicurity" tailored to the specific circumstances of each (Wilthagen, 2008). On the other hands, one should argue that flexicurity, very much like the debate on the OMC, remains within the confines of supply-side measures dealing with labour market problems. Combining different pathways and no-one-sizefits-all discourse reveals that national autonomy has been respected. However, the alternatives for member states have been limited.

It must be noted at this point that the Commission's views can be deconstructed at will. However and at least to a certain extent, there are also important arguments and proposals for the labour market entailed in the Commission proposals that cannot be rejected by anybody. In other words, the general Commission's views are based on a "polysemic discourse" (Daguerre, 2007), which could play into the hands of many different positions. For example, there are certain measures inspired by the activation discourse such as preventing welfare dependency, rights together with responsibilities, making search for work more attractive and so on. At the same time, there are calls for equal employment, the importance of social dialogue and reconciliation of family and work. This polysemy stems largely from the vagueness and ambiguous formulations of the Commission. The Commission as a broker between different interests has to be very careful while presenting its views in order not to discourage some specific actors from engaging in the debate. However, it is fair to argue that the Commission is not neutral to all sides of this debate. It has a clear agenda concerning the labour market reforms. At the same time, remaining vague as to proposing concrete measures on how to reach its recommendations, the Commission does not push other actors out of the debate.

9 Wilthagen, after his presentation, replied to a question of "why does the Commission chose not to use composite indicator?" in the way quoted above. 
Dealing with the role the Commission played in the debate on flexicurity, some important points deserve to be noted. Weiss and Wodak talk about the "committee regime of EU policy-making"10, understood as "the many highly specialized expert groups developing programs, concepts, strategies in their respective policy fields" (Weiss and Wodak, 2000:187-8). Their existence replaced political legitimacy by functional legitimacy. At the same time, the trend towards them reflects a "de-politicization"11 of policy-making in the traditional sense (Ibid:189). It has also been the case within the Commission in terms of flexicurity. Within this framework, we see the establishment of the "European Expert Group on flexicurity" and some methodologically flawed reports (such as Eurobarometer October 2006) as an exercise of "political communication" (Barbier, 2007:180).

Jepsen and Serrano Pascual note that political discourse and research are intertwined considering the proposals from the Commission, "which are supported by research for legitimating to make controversial political arguments pass for objective scientific conclusions" (Jepsen and Serrano Pascual, 2005:233). The Commission has established the European Expert Group on flexicurity ${ }^{12}$ in July 2006. The interim and final reports of the expert group have been used heavily by the Commission in its 2007 Communication towards common principles of flexicurity. This close connection between the Commission and the expert group opens up the debate for the above mentioned role the scientific studies play. This does not mean that the expert group is only about legitimating the policy proposals of the Commission. However, the conclusions derived from these studies are presented as "neutral and scientific", thus "overshadowing the highly political nature of the decisions being made"13. This helps Commission to produce, reproduce and transform political and ideological positions of other decision-making bodies (Weiss and Wodak, 2000:192).

Barbier considers the addition of the Europeans' approval of the concept of flexicurity to the Eurobarometer survey (Eurobarometer October 2006) and argues that within the frame of a single question ${ }^{14}$, the Commission concluded by saying "a large majority of citizens agree with all

10 "Committee regime" is also related to what is called as "policy-entrepreneurs"- the bureaucrats acting as political actors rather than executive agents of the political systems - and "epistemic communities" - transnational knowledge and expertise communities. (p.187-188).

11 Weiss and Wodak (2000), in their work on the Competitiveness Advisory Group' (CAG) political program noted that the program was designed to deconstruct unemployment as a political program, presenting it as an economic reality (p.201).

12 The expert group was established in July 2006 by the Directorate-General for Employment, Social Affairs and Equal Opportunities. It consists of experts chosen on the basis of their academic record and two other experts as advisors from the social partners. "The group's main task was to review relevant academic literature and practices in member states and to advise the Commission on preconditions for flexicurity, various starting positions and flexicurity pathways" (see European Expert group on flexicurity, 2007:3). Interestingly, Ton Wilthagen - the rapporteur of the group - acknowledged that "officially the mission was developing core principles but within time, also showing the concrete ways how to go there, in other words, the pathways were also becoming part of it" (Interview with Ton Wilthagen, January 17, 2008 at Antwerp/Belgium).

13 Quoted in Jepsen and Serrano Pascual, 2005:233.

14 The question was "please tell me, for each of the following statements to what extent you agree or disagree with it: regular training improves one's job opportunities; life time jobs with the same employer are a thing of past; Being able to change easily from one job to another is a useful asset to help people find a job nowadays; Work contracts should become more flexible to encourage job creation; In (our country) many people retire too early" (Barbier, 2007:180). 
the proposals and thus indirectly agree with the concept of flexicurity (between $72 \%$ and $88 \%$ )" (Barbier, 2007:180). The support for flexicurity has been made measurable with a single question.

\section{European Parliament}

The European Parliament (EP), in its report on common principles of flexicurity (European Parliament, 2007), does not present a position that is in line with the Commission's. In Keune's words, it is "a more comprehensive opinion" and "it takes a number of positions that contradict the Commission" (Keune, 2007:8). Analysing the EP's resolution in detail is beyond this paper's aim but, at this point, it is vital to note the main points that the Parliament adopts. Among those, the most important one concerns the Commission's general interpretation of the term; the EP Report notes that "the interpretation of the Commission's flexicurity options is too one-sided" (see also Keune, 2007:8). Related to this observation, while calling on the European Council in December 2007 to adopt "a more balanced" set of common principles of flexicurity, the EP tries to focus attention on "the quality of employment". Thus, it clearly states that the Commission's position is not balanced enough with respect to flexibility and security. The EP clearly states that related with the gender dimension, "the Commission's communication completely disregards the obligations and responsibilities" set out in its own communications - A Roadmap for equality between women and men (2006) and Tackling the pay gap between women and men (2007). Another noteworthy point is that the EP strongly highlights the necessity of "a supportive macroeconomic environment" in the debate. Other important disagreements between the EP and the Commission are the Commission's distinction between insiders and outsiders and the creation of a new indicator on the strictness of employment protection legislation. At this point, the EP's resolution does not forget to note the recent OECD statement admitting that "employment protection legislation has no significant impact on the total employment rate".

It is obvious in the EP's resolution that more flexibility is needed in order to deal with the challenges of the $21^{\text {st }}$ century. Flexibility should mainly be achieved through improving education, expanding training, removing the obstacles to mobility and providing transition security. But, what differentiates the EP's position is that it is talking about "job insecurity" and for this matter, it calls for "improving job security", maintaining "the traditional model of open-ended contracts". The EP also acknowledges the need to improve employment security.

To conclude, while considering the Commission's view as "too one-sided", the EP believes that "a more balanced" view on flexicurity must also take the security side (not only employment but also job security) into consideration.

\section{Council of the European Union}

The Council of the European Union released a document with eight flexicurity principles that are very much in line with the Commission's propositions on 5-6 December 2007. Keune (2007 and 2008) argues, however, that there is an important statement in the Council Conclusions (2007: 5) that deserves to be noted due to the fact that it contradicts the Commission's understanding of 
flexibility, in particular in terms of contract and employment protection (Keune, 2008:97) and the Commission's view that "EPL should be low" (Keune, 2007:7).

The inactive, the unemployed, those in undeclared work, in unstable employment, or at the margins of the labour market need to be provided with better opportunities, economic incentives and supportive measures for easier access to work or stepping-stones to assist progress into stable and legally secure employment (quoted in Keune, 2007:7-emphasis in original).

Another interesting thing to note is the fact that in the Council Conclusions, "the need to promote the awareness of citizens of flexicurity policies and their importance" is referred to two times. The Commission is asked to "launch a public initiative in close cooperation with the European Social partners... and to raise the awareness of citizens of flexicurity..." (Council of the European Union, 2007:3-4). This demand paved the way for the launching of a public initiative, in the form of a Mission for Flexicurity. This mission seems to be quite in line with the observation of the Commission's attempts to highlight the need for a communication strategy in order to stem the criticism exerted on the Commission by the EU public, a criticism often due to a lack of sufficient

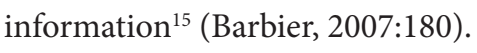

\section{BusinessEurope}

The Confederation of European Business (BusinessEurope) ${ }^{16}$, the largest European employers' organization, now consists of 40 members from $34 \mathrm{EU}$ and non-EU countries. BusinessEurope, together with UEAPME (European Association of Craft, Small and Medium-Sized Enterprises), CEEP (European Centre of Enterprises with Public Participation and of Enterprises of General Economic Interest), and ETUC (European Trade Union Confederation) has been part of the European Social Partners' "Joint analysis of the key challenges facing European labour markets" released at October 2007, just after the Commission's Communication on 27 June 2007. BusinessEurope has released a "Position Paper on the Commission's Communication 'Towards Common Principles of Flexicurity" on 6 November 2007 in which its main arguments were presented.

After analysing their position paper, one may initially think that BusinessEurope is probably the actor that has a position most similar to that of the Commission (see also Keune, 2007:8). On many points, namely "the restrictive character of the Employment Protection Legislation" (EPL); "the main components of flexicurity"; "no one-size-fits-all model" considering different national situations; and "the role of the social partners", BusinessEurope sides with the Commission (Business Europe 2007b). According to Philippe de Buck, the then-Secretary General of

15 Barbier (2007:180) notes that the Constitutional crisis led the Commission to accelerate its communication policy. Also, the Commission evaluated the European citizens' indifference and hostility to Lisbon Strategy because of their lack of information.

16 The organization changed its name into BusinessEurope in 2007. The original name was the "Union des Industries de la Communauté européenne" (UNICE). 
BusinessEurope, "flexicurity is to go from a job preservation mind-set to a job creation mind-set"17. This view is also noted in their position paper; "job creation" is the main part of BusinessEurope's discourse (BusinessEurope, 2007b:2). While introducing the details of the job creation mind-set, de Buck argues that "there is a shared responsibility for companies, governments and peoples themselves". Explicitly, the responsibility of people, according to de Buck, is "to make sure that they increase their skills, they are trained". This must be understood in a context suggesting that flexicurity is to change the way the social models in Europe function (BusinessEurope, 2007a).

The EP's report on the common principles of flexicurity is appreciated by BusinessEurope and is considered as full-fledged support to the Commission's initiatives ${ }^{18}$, deliberately or unintentionally not considering or noting the serious reservations of the EP in the report's interpretation of flexicurity.

To sum up, BusinessEurope's position is in line with the Commission's. The main emphasis is on job creation, but, whether it is a better job does not seem to be important. Another noteworthy point is that, explicit in the words of de Buck on peoples' responsibility, to a great extent, is that the "individualization" approach which claims that the cause of unemployment is the inappropriate job skills of unemployed people, is supported by BusinessEurope.

\section{The European Trade Union Confederation (ETUC)}

The ETUC was founded in 1973; it now represents 90 national trade union confederations in 39 countries, plus 10 European trade union federations. It is involved in economic and social policy-making at the highest level, working with all EU institutions. At the same time, the ETUC negotiates with the employers at European level through the European Social Dialogue.

The ETUC, to a great extent, reasons differently from the Commission and BusinessEurope in the flexicurity debate. The ETUC is very much concerned with the ongoing debate on the concept of flexicurity, as the then-General Secretary of the ETUC, John Monks stated. The real agenda, according to the ETUC, is different from what is proclaimed. "Hiding behind flexicurity simply seems to be the dismantling of job protection"19; hence, the most important point for the ETUC is the issue of giving up job protection in return for employment security ${ }^{20}$. John Monks argues that the emphasis on lifelong learning as a new type of security means the withdrawal of your

17 BusinessEurope (2007a): "Philippe de Buck" on flexicurity, October 18, http://www.businesseurope.eu/content/ Default.asp?PageID=526 [Retrieved on February 23, 2008].

18 The then- President of the BusinessEurope Ernest-Antoine Seillière said: "In their joint labour market analysis, European social partners agreed that flexicurity is the right step forward to modernise European labour markets. The European Parliament's report now adds to the growing consensus that flexicurity is key to allow companies and workers to seize new opportunities and enhance their adaptability" (see BusinessEurope, $(2007 \mathrm{c})$ "European Parliament vote shows support to flexicurity", Press Release, November 29).

19 Euractiv (2007a) "Social partners on flexicurity and labour-market reforms", available at http://www.euractiv.com/ en/socialeurope/social-partners-flexicurity-labour-market-reforms/article-164260, [Retrieved on August 26, 2007].

20 Introduction by John Monks, General Secretary of the ETUC at the "Stakeholder Conference on flexicurity". Available at http://etuc.org/a/3593, [Retrieved on August 26, 2007]. 
benefits if you do not take up alternative work, even when this is a work of worse pay and working conditions. On the other hand, Monks (ETUC, 2007a) expresses that:

"Yet I am not negative about flexicurity. I just want to "recapture the debate" from those who want to concentrate on reducing employment protection and unemployment benefits entitlements" (emphasis added).

Monks listed some important points that ETUC wants recognised in the flexicurity debate: These are a) more and better jobs; b) the respect and promotion of the role of social partners; $c$ ) a fight against precariousness and undeclared work; $d$ ) a focus on upward mobility to help workers find not just new but better jobs; e) the integration of flexicurity with macroeconomic policy ${ }^{21}$.

The ETUC clearly opposes the ideas of some member states and the Commission on the reduction of EPL in the hope of making the European labour markets more flexible and dynamic. It argues that Europe is already enjoying high adaptability, and referring to the OECD's latest statements on the issue of the EPL, it notes that "advance notification of dismissal is beneficial on the ground that it gives workers the chance to look for a new job, in this way reducing the time spent in unemployment"22.

In its Position Paper on the Commission's Communication ${ }^{23}$, the ETUC presented its evaluation of the Commission's views. Its conclusion was that the Commission's Communication is not balanced regarding the flexibility and security elements. The ETUC argued the irrelevancy of the arguments proposed by the Commission's Communication in a concrete way. Concerning active labour market policies, lifelong learning and employment security, the ETUC argues that the Commission's tone is on workfare rather than learn-fare approach without paying due attention to the quality of jobs made available. On the issue of the principles of flexicurity, the ETUC notes that the Commission's views are not consistent and are characterised by vagueness. The Commission's calls for some principles - such as the need for rights and responsibilities to be balanced, improving gender equality, supporting the social dialogue, no one-size-fits-all and so on - are welcomed. However, the ETUC has serious concerns on some issues - such as giving priority to external flexibility at the expense of others, the absence of a clear reference to macroeconomic policies because of the argument that easy firing creates more jobs and so on. Lastly, regarding the indicators the ETUC worries about the Commission's proposal to include the OECD indicator of strictness of employment protection to the background indicators relevant for flexicurity. This would pull the strategy in one particular direction, according to the ETUC.

In short, the ETUC considers that the debate on the balance of flexibility and security should not be seen as separate from the agenda of "quality of jobs". Like the EP, the ETUC considers employment security as a complement, rather than an alternative, to job security (Keune 2008:98).

21 Ibid.

22 ETUC (2007b) “The Flexicurity debate and the Challenges for the Trade Union Movement", available at http://etuc. org/a/3588, [Retrieved on August 26, 2007].

23 ETUC (2007c) "ETUC's position adopted by the ETUC Executive Committee of 17-18 October 2007", available at http://www.etuc.org/a/4233, [Retrieved on January 17, 2008]. 
Following the outline on the main European institutional actors on flexicurity, a number of critical aspects can be noted with respect to the use of the concept in documents such as the Presidency Conclusions, the Green paper on labour law, the Communication and so on. What predominates is (adopted from Rogowski, 2007:9-10 and Rogowski, 2008:86-7):

- a vagueness in the definition of the term flexicurity, which seems crucial for the success of flexicurity policies and which permits its use for the expression of a wide range of almost contradictory policy goals;

- the term flexicurity expresses an aspiration rather than a concrete policy, despite efforts to define common principles and translating them into measures

- the notion of flexicurity carries positive connotations of balancing (of interests), integration (of different reform efforts) and inclusion (of actors) and avoids addressing negative consequences. In that way, it becomes seen as politically neutral to maximum effect.

- flexicurity is assessed as an opportunity, adding urgency to the need for labour market and social policy reforms, and downplays caution and restraint in reforming established systems of welfare protection.

Having provided the positions of key European institutions on the flexicurity, it fair to argue that all actors acknowledge the importance of it in dealing with the European labour market problems. However, they have very different ideas especially when it comes to the issue of how to translate this ambiguous concept of flexicurity into concrete policies. Especially relevant for the differences between the views of the BusinessEurope and ETUC, it seems that the traditional positions of these institutions are "now represented under the heading of flexicurity" (Burroni and Keune, 2011:78).

\section{Flexicurity: A Deliberate Ambiguity}

In lieu of the conclusion of the debate at the EU level, the following observation of Keune (2008: 98) deserves to be quoted at length:

"It can be seen that there is no European consensus on flexicurity. The ambiguous nature of the flexicurity concept makes it possible for everyone to subscribe to its importance. At the same time, different actors have quite different understandings of the concept... The concept is widely open to interpretation and different actors put forward quite different versions of flexicurity, using it as a banner to promote their traditional views on labour market reforms."

The above observation has addressed the main argument of this paper at this point, albeit indirectly. The ambiguity referred to in the above quotation, which makes the term flexicurity very attractive, is not an "ordinary ambiguity". As Keune rightly argues, everyone is happy with 
the term because they are able to put in it what they want, due to the lack of a general framework and a theory of the concept. This ambiguity stems also from the EES (in particular from its guidelines). The "vague" and "ambiguous" conceptualizations of the concept by the Commission are instrumentalized in order to play one of its main roles as the broker of interests between different actors through letting them articulate their views, while at the same time giving the impression that they should move the framework of the debate in its desired direction ${ }^{24}$. In other words, the argument here is that there are many different interests embedded in the concept and through loose definitions and vague arguments, you can absorb all the main actors into the debate through letting them jump to the bandwagon in order to give the image that they can also shape and recapture the debate ${ }^{25}$.

Bredgaard and Larsen ${ }^{26}$ in their article Comparing flexicurity in Denmark and Japan note the following observation, in line with the above argument, as a reason for the increasing popularity of the concept:

"One important reason for the increasing popularity of the concept is probably the very fact that the concept is so hard to define, and consequently different actors can mould the concept to fit their own interpretations and interests. Here lies one possible explanation as to why flexicurity has become a semantic magnet to which the EU Commission and the OECD, for example, have found themselves attracted. This lack of conceptualization and concretization implies a certain political ambiguity and timidity" (Bredgaard and Larsen, 2007:5).

This "certain political ambiguity and timidity", at the same time, gives certain legitimacy to the main initiator of the concept and the debate. This plays into the hands of those (especially the Commission due to its pivotal role in promoting concepts and shaping the nature of the debates) promoting the concept as a cure to the current challenges that European labour markets face. Putting it differently, the concept is very much a political construct of a political project directed towards deliberately created common problems (Jepsen and Serrano Pascual, 2005). According to this paper, this ambiguity on flexicurity is not an ordinary ambiguity but, a "deliberate ambiguity".

24 Daguerre (2007:145) argues that due to the increasing neoliberal stance of the new Barroso Commission on social and economic policies, the Directorate General for Employment, Social Affairs and Equal Opportunities favoured the emergence of compromises to the detriment of political clarity. This search for consensus explained, at least partially, the structural ambiguity of the employment guidelines.

25 At the expense of recalling, as an example the statements of John Monks at the Stakeholder conference on flexicurity are very instructive: "Yet I am not negative about flexicurity. I just want to recapture the debate from those who want to concentrate on reducing employment protection and unemployment benefit entitlements, and from those who are giving the impression that the way to tackle the issue of precarious work is to make regular work more precarious" (ETUC, 2007a - emphasis added).

26 Bredgaard and Larsen quoted Jean-Claude Barbier (2006) in order to justify their argument on the "ambiguity of the concept": "No political document published by the Commission or the OECD has -so far-been able to present a coherent, comprehensive and detailed economic model of a "nexus" between flexibility and security" (quoted in Bredgaard and Larsen, 2007:5 - emphasis in original). 


\section{Conclusion}

With regard to the flexicurity debate at the EU level, the Commission, due to its preponderance in decision-making and giving a direction to the overall debates, has been very active in pushing the concept to the top of the European agenda. But, for the time being, to speak about a European consensus on the concept is not realistic. The other main European actors in this policy area have some reservations towards the Commission's reasoning but they are not negative about flexicurity. Nevertheless, the Commission seems to be victorious in terms of getting other sides to accept the basic tenets of the debates it has been advocating. Having argued for the ambiguous nature of flexicurity and the role the Commission has been playing in the debate at the EU level, this paper has also argued that the ambiguity associated with the concept, at the EU level, is not an ordinary ambiguity, but a deliberate ambiguity.

Since 2006, we have been witnessing increasing efforts at the EU level (especially by the Commission) to push the concept to the top of the political/economic agenda. In the previous periods, the need for a fine balance between flexibility and security in the labour markets had been considered within the confines of the European Employment Strategy, and in particular falling under the adaptability pillar. According to this paper, this timing is not accidental. The failure of the Constitutional Treaty in France and the Netherlands in 2005 was a clear manifestation of the decreasing legitimacy of the integration project and of its supranational bodies, namely the Commission ${ }^{27}$. The mid-term revision of the Lisbon Strategy in which the Employment Guidelines together with the Broad Economic Policy Guidelines were incorporated to the Integrated Guidelines was considered as prioritizing the flexibility needs over security ${ }^{28}$. They have led the Commission to show a social face, by using the concept of flexicurity, in order to neutralise the present antagonisms directed against it by its opponents. This observation necessitates a clear investigation in order to argue whether the term flexicurity has transformed

27 According to many (Keune, 2007 and 2008; Barbier, 2007 and Bertola, 2006), the rejection of the Treaty Establishing a Constitution for Europe by the French and Dutch electorates was a clear manifestation of the concerns about "social Europe". Needless to note, this was an important crisis to be dealt with for the EU. French citizens who gave a 'no' vote to the EU Constitution, according to Eurobarometer (2005), listed "loss of jobs" (31 percent), "too much unemployment" (26 percent), "economically too liberal" - meaning the Constitution - (19 percent) and "not enough social Europe" (16 percent) among the top five reasons. Similarly, "joblessness and other economic problems" were also cited by Dutch voters as a reason for rejecting the treaty (quoted in Bertola, 2006:192). Keune notes the message underlining the fact that "look Europe, you are not social enough" which paved the way for the Commission to start to feel that "we have to show a social face to public". This message was interpreted by the Commission as the need to step up its communication strategy (Barbier, 2007:180). Within this framework, one should conclude that the term flexicurity, to a certain extent, has started to be pushed to the top of the agenda considering European labour market reforms in order to give the message that the social concerns of the citizens are taken into consideration. This is not to argue that the failure of the Constitutional Treaty was the main reason, but nevertheless it played an important role and accelerated the process. In short, the double rejection of the EU Constitution led to a change in the policies and discourses of the Union. Now, the need for a new strategy or a framework is clear. Still, the main problem is whether the new strategy or framework was really new or was it only a change in the discursive tool rather than in the discourse.

28 Jørgensen and Madsen note that "the mid-term revision of the strategy in 2005 could also be seen as a kind of midway crisis, as the economic elements was strengthened to the disadvantage of the social elements. Rhetoric is intact, but in reality 'security' and welfare was supposed to be placed on the back burner" (Jørgensen and Madsen, 2007:21). 
the overall debate on the issue of Social Europe. The conclusion reached after the investigation is that flexicurity seems a new discursive tool rather than a change in the discourse that has existed for many for years. The concept of flexicurity seems only to be replacing older concepts such as activation, transitional labour markets and the European Employment Strategy. Consequently, the discourse remains intact but the tool to reach the aims expressed in the overall discourse has changed.

Few words should be noted for the possible future of the concept. The concept contains the danger of disappearing due to the ambiguity of its nature. In the words of Jørgensen and Madsen (2007:31):

"Perhaps it is the present lack of a precise and concrete concept of flexicurity used by the EU institutions that has secured the European success and status as a celebrity. A non-precise meaning can make flexicurity politically harmless. But if the concept and the strategy is defined too broad and all-encompassing it will soon be scraped again - and then you could talk of a pyrrhic victory for flexicurity."

Jørgensen and Madsen seem to be right. Although it is reaffirmed in the EU-2020 strategy and Commission's 2012 Communication entitled Towards a Job-Rich Recovery, flexicurity seems to have started losing its attractiveness especially within the course of the economic crisis of 2007-2008 (Nardo and Rossetti, 2013) ${ }^{29}$. It seems not a low possibility that the flexicurity in the near future may face discursively new formulated concepts indicating the message of balancing security needs of employees and flexibility needs of employers.

29 The following passage from Nardo and Rossetti (2013:3) seems to support this view: "After a decade of bonanza the economic crisis brought rising unemployment levels, decreased and in some cases even negative real GDP growth and scaled-back income-security policies, reducing the attraction of flexicurity. Most European Countries are facing increased inequality and social tensions, tighter budget balance constraints together with growing government expenditures to finance the considerable growth in unemployment rates, effectively reducing the scope for activation and other support measures. The 'double bind' of flexicurity seems therefore jeopardised". 


\section{References}

Ashiaghbor, D. (2005) The European Employment Strategy, New York: Oxford University Press.

Barbier, J., C. (2007) "From political strategy to analytical research and back to politics, a sociological approach of "flexicurity"' in Jørgensen, H. And Madsen, P., K. (eds.), Flexicurity and Beyond: Finding a New Agenda for the European Social Model, Copenhagen, Denmark: DJOF Publishing 155-189.

Bekker, S. (2007) "Flexibility and security in the adaptability of the EES: A Study of Commission Guidelines and Recommendations and Countries' Responses", Paper for the $5^{\text {th }}$ International Research Conference on Social Security: Social security and the labour market: A mismatch? International Social Security Association, Warsaw, 5-7 March 2007, 1-29.

Bercusson, B. (ed.) (2007) "Manifesto for a Social Constitution: 8 options for the European Union", European Trade Union Institute for Research, Education and Health and Safety (ETUI-REHS), Brussels, p. 1-133, http://www.etui-rehs.org/en/content/search?SearchText=manifesto+social+constitution [July 10, 2008].

Bertola, G. (2006) "Social and labour market policies in a growing EU”, Swedish Economic Policy Review, vol.13: 189-231.

Bredgaard, T. and Larsen, F. (2007) “Comparing Flexicurity in Denmark and Japan”, Tokyo: Japan Instıtute for Labour Policy and Training (JILPT), JILPT Research Report, http://www.samf.aau.dk/ thomas/ JILPT\%20report-final\%5b1\%5d.pdf [March 12, 2008].

Burroni, L. and Keune, M. (2011) "Flexicurity: A conceptual critique", European Journal of Industrial Relations 17(1): 75-91.

BusinessEurope (2007a) "Philippe de Buck on flexicurity", http://www.businesseurope.eu/content/default. asp?Pageid=526 [February 23, 2008].

BusinessEurope (2007b) "6 November 2007 Position Paper: Commission Communication towards Common Principles of Flexicurity”, http://www.businesseurope.eu/content/default.asp?pageid=426 [July 10, 2008].

BusinessEurope (2007c) "European Parliament vote shows support to flexicurity", November 29, 2007, http:// www.businesseurope.eu/content/default.asp?pageid=426 [February 23, 2008].

Büchs, M. (2007) New Governance in European Social Policy: The Open Method of Coordination, New York: Palgrave Macmillan.

Commission of the European Communities (CEC) (2006a) Employment in Europe 2006, Luxembourg: Office for Official Publications of the European Communities.

CEC (2006b), Modernizing the Labour Law to Meet the Challenges of the 21st Century, Green Paper, COM (2006) 708 final, Brussels.

CEC (2007), Towards Common Principles of Flexicurity: More and Better Jobs through Flexibility and Security, Communication from the Commission to the European Parliament, The Council, The European Economic and Social Committee and The Committee of the Regions, COM (2007) 357 final, Brussels, 27 June 2007.

Council of the European Union (2007) Council Conclusions: Towards Common Principles of Flexicurity, adopted on 5/6 December 2007.

Daguerre, A. (2007) Active Labour Market Policies and Welfare Reform: Europe and the US in Comparative Perspective, New York: Palgrave Macmillan.

Economist (2007) “In the Shadow of Prosperity”, vol. 382(8512), 20 January 2007.

ETUC (2007a) "Stakeholder conference on flexicurity”, http://www.etuc.org/a/3593 [August 26, 2007].

ETUC (2007b) “The Flexicurity Debate and the Challenges for the Trade Union Movement”, http://www. etuc.org/a/3588 [August 26, 2007]. 
ETUC (2007c) "ETUC's position adopted by the ETUC Executive Committee of 17-18 October 2007", http:// www.etuc.org/a/4233 [January 17, 2008].

EurActiv (2007a) "Social Partners on flexicurity and labour market reforms", http://www.euractiv.com/ en/socialeurope/social-partners-flexicurity-labour-market-reforms/article-164260 [August 26, 2007].

EurActiv (2007b) “Trade Unions and employers clinch deal on flexicurity", http://www.euractiv.com/en/ socialeurope/trade-unions-employers-clinch-deal-flexicurity/article-167750 [December 20, 2007].

European Expert Group on Flexicurity (2007) "Flexicurity Pathways: Turning hurdles into stepping stones", Report by the European Expert Group on Flexicurity, June 2007, 1-41, http://ec.europa.eu/ employment_social/employment_strategy/pdf/flexi_pathways_en.pdf [July 10, 2008].

European Industrial Relations Review (2006) “Flexicurity in the spotlight”, Issue 395, December 2006, 27-32.

European Parliament (2007) European Parliament resolution of 29 November 2007 on Common Principles of Flexicurity, 2007/2209(INI), Brussels.

Fitch, S. (2007) “Copenhagen Capitalism”, Forbes, vol.179(5), 12 March 2007.

Frederiksen, C. H. (2007) "Flexicurity", Speech of the Danish Minister for Employment at a conference organized by European Commission on "Pathways towards a better combination of flexibility and security”, April 20, 2007, Brussels, http://www.bm.dk/sw19898.asp [September 20, 2007].

Jepsen, M. and Serrano Pascual, A. (2005) "The European Social Model: an exercise in deconstruction", Journal of European Social Policy, vol.15(3): 231-245, http://esp.sagepub.com [May 11, 2007]

Jørgensen, H. and Madsen, P.; K. (2007) "Flexicurity and Beyond - Reflections on the Nature and Future of a Political Celebrity", in Jørgensen, H. And Madsen, P., K. (eds.), Flexicurity and Beyond: Finding a New Agenda for the European Social Model, Copenhagen, Denmark: DJOF Publishing 7-35.

Keune, M. (2007) “Flexicurity as the new labour market model for the European Union?", Paper presented at the conference 'Are flexibility and security compatible in the labour market?', Future of Work Conference Series, Caixa Sabadell's Obra Social and Sabadell City Council, Sabadell, Spain, 12 November 2007.

Keune, M. (2008) "Flexicurity: A Contested Concept at the Core of the European Labour Market Debate", Intereconomics, March/April 2008, 92-98.

Keune, M. \& Jepsen, M. (2007) "Not balanced and hardly new: the European Commission's quest for flexibility", European Trade Union Institute for Research, Education and Health and Safety (ETUIREHS), Brussels, 1-24, http://www.etui-rehs.org/research/activities/Employment-and-socialpolicies/Reports-and-discussion-papers/WP-2007.01 [December 17, 2007].

Keune, M. and Serrano Pascual, A. (2014) "The Power to Name and Struggles over Meaning: The Concept of Flexicurity" in Maarten Keune and Amparo Serrano Pascual (eds.), Deconstructing Flexicurity and Developing Alternative Approaches: Towards New Concepts and Approaches for Employment and Social Policy, New York: Routledge.

Nardo, M. and Rossetti, F. (2013) "Flexicurity in Europe", Report prepared for the use of the European Commission, Directorate-General for Employment, Social Affairs and Inclusion, 1-82.

Rogowski, R. (2007) “Governance of EU Social and Employment Policies as Reflexive Coordination”, Paper presented at the Workshop on Multi-level Governance, Centre for the Study of Globalisation and Regionalisation, May 17-19, 1-23.

Rogowski, R. (2008) “Governance of the European Social Model: The Case of Flexicurity”, Intereconomics, March/April 2008, 82-91.

Scharpf, F. (2002) “The European Social Model: Coping with the Challenges of Diversity”, MPIfG Working Paper 02/8, 1-24. 
Seifert, H. (2008) "Flexicurity: between theory and empirical evidence", Paper presented at the conference 'Flexicurity and the Lisbon Strategy', Lessius University College, Antwerpen, Belgium, 17 January 2008.

Serrano Pascual, A. (2009) "The battle of ideas in the European field: the combat to defeat unemployment and the struggle to give it a name", Transfer: European Review of Labour and Research 15(1): 53-70.

Serrano Pascual, A. and Crespo Suárez, E. (2007) “The government of activation policies by EU institutions”, International Journal of Sociology and Social Policy, vol.27(9/10): 376-386.

USA Today (2007) “Denmark’s flexicurity blends welfare state, economic growth”, March 07, 2007.

Weiss, G. and Wodak, R. (2000) "Discussion: The EU Committee Regime and the Problem of Public Space" in Muntigl, P., Weiss, G and Wodak, R. (eds.), European Union Discourses on Un/employment: An Interdisciplinary Approach to Employment Policy-making and Organizational Change, Amsterdam/ The Netherlands: John Benjamin Publishing Company, 185-207.

Wilthagen, T. (2008) "Flexicurity: concepts, principles and pathways", Paper presented at the conference 'Flexicurity and the Lisbon Strategy', Lessius University College, Antwerpen, Belgium, 17 January 2008.

Wilthagen, T. \& Tros, F. (2004) “The concept of 'flexicurity': a new approach to regulating employment and labour markets”, Transfer 10(2): 166-186.

\section{List of Interviews}

Jannsen, R. (Advisor of flexicurity department of the ETUC), Interview by author, ETUI-REHS, Brussels/ Belgium, 22 January 2008.

Jepsen, M. (Head of ETUI-REHS Research department and Associate Professor at Université Libre de Bruxelles), Interview by author, ETUI-REHS, Brussels/Belgium, 22 January 2008.

Keune, M. (Senior Researcher at ETUI-REHS), Interview by author, Lessius University College, Antwerp/ Belgium, 17 January 2008.

Wilthagen, T. (Professor at Tilburg University/The Netherlands and Rapporteur of the Commission's European Expert Group on Flexicurity), Lessius University College, Antwerp/Belgium, 17 January 2008. 